BNL 50637

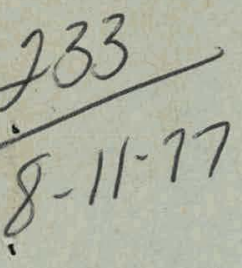

\title{
INDIVIDUAL AIR POLLUTION MONITORS. 2. \\ EXAMINATION OF SOME NONOCCUPATIONAL RESEARCH \\ AND REGULATORY USES AND NEEDS
}

M. Granger Morgan and Samuel C. Morris
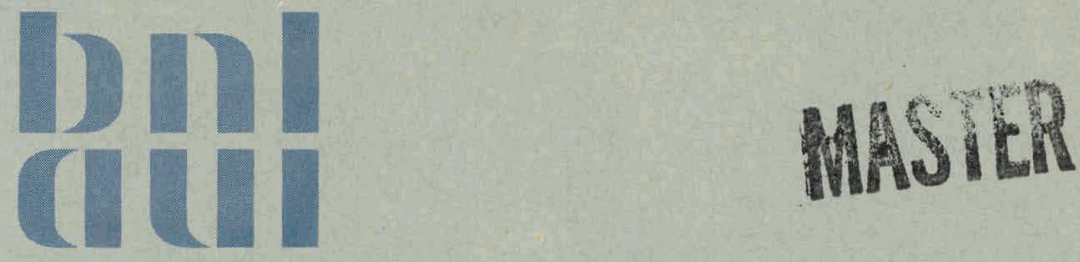

January 1977

MASTER

BIOMEDICAL AND ENVIRONMENTAL ASSESSMENT DIVISION

NATIONAL CENTER FOR ANALYSIS OF ENERGY SYSTEMS

BROOKHAVEN NATIONAL LABORATORY ASSOCIATED UNIVERSITIES, INC. UINDER CONTRACT NO. EY-76-C-02-0016 WITH THE UNITED STATES ENERGY RESEARCH AND DEVELOPMENT ADMINISTRATION 


\section{DISCLAIMER}

This report was prepared as an account of work sponsored by an agency of the United States Government. Neither the United States Government nor any agency Thereof, nor any of their employees, makes any warranty, express or implied, or assumes any legal liability or responsibility for the accuracy, completeness, or usefulness of any information, apparatus, product, or process disclosed, or represents that its use would not infringe privately owned rights. Reference herein to any specific commercial product, process, or service by trade name, trademark, manufacturer, or otherwise does not necessarily constitute or imply its endorsement, recommendation, or favoring by the United States Government or any agency thereof. The views and opinions of authors expressed herein do not necessarily state or reflect those of the United States Government or any agency thereof. 


\section{DISCLAIMER}

Portions of this document may be illegible in electronic image products. Images are produced from the best available original document. 


\title{
INDIVIDUAL AIR POLLUTION MONITORS. 2. \\ EXAMINATION OF SOME NONOCCUPATIONAL RESEARCH \\ AND REGULATORY USES AND NEEDS
}

\author{
M. Granger Morgan* and Samuel C. Morris
}

\section{January 1977}

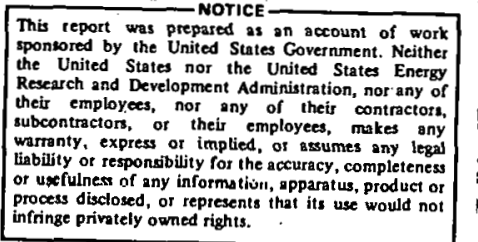

*Electrical Engineering and Engineering and Public Policy, Carnegie-Mellon University, Pittsburgh, Pennsylvania 15213

BIOMEDICAL AND ENVIRONMENTAL ASSESSMENT DIVISION NATIONAL CENTER FOR ANALYSIS OF ENERGY SYSTEMS 


\section{NO T I C E}

This report was prepared as an account of work sponsored by the United States Government. Neither the United States nor the United States Energy Research and Development Administration, nor any of their employees, nor any of their contractors, sulsuintractors, or thelr empluyess, miskri ainy warranty, orprese or implied, nr assumes any legal liability or responsibility for the accuracy, completeness or usefulness of any information, apparatus, product or process disclosed, or represents that its use would nut infringe privatcly owned rights.

Printed in the United States of America Avarlable from

National Technical Information Service

U.S. Department of Commerce 5285 Port Royal Road Springfield, VA 22161

Price: Printed Copy $\$ 3.50$; Microfiche $\$ 3.00$ 


\section{PREFACE}

This report combines materials previously published in our workshop report Individual Air Pollution Monitors. An Assessment of National Research Needs with a review of much of the available experimental literat.ure on the relation between fixedstation monitoring data and individual dose, and some additional work of our own. We present this in order to provide a more concise and comprehensive argument for the establishment of a national research and development program for individual air pollution monitors than is given in the workshop report. 


\begin{abstract}
Knowledge of the relationship between ambient air pollution levels measured at fixed monitoring stations and the actual exposure of the population is very limitcd. Indeed, there is rapidly growing evidence that fixed-station monitors do not provide adequatc data for population exposure. This report cxamines available data for carbon monoxide $(\mathrm{CO})$ and sulfur dioxide $\left(\mathrm{SO}_{2}\right)$ and presents a new analysis. Actual population exposure to $\mathrm{CO}$ appears to be consistently higher than expected from fixed-station data, while limitcd evidence suggests that exposures to $\mathrm{SO}_{2}$ are lower. A reported general relationship between indoor and outdoor levels of $\mathrm{SO}_{2}$ is nol supported by the data. If air pollution represents a threat to public health, then more attention must be given to total population exposure to pollutants.

A selective use of individual air pollution monitors that can be worn or carried appears to be required at some stage by any experimental design seeking to uncover the relation between air pollution exposure and hedill $\mathrm{h}_{1}$ effects. Additionally, potential uses of individual monitoring in air pollution regulation are explored.

Current status and research needs for individual air pollution monitors are examined and a first-order evaluation is given of the promise held by the candidate instrumentation technologies. A national program of support for the development of individual air pollution monitors is recommended.
\end{abstract}




\section{CONTENTS}

Preface.

Abstract .

iv

INTRODUCTION

1

Ambient Leveis and Individual Exposure.

Individual Monitors in Health Effects Studies.

1. Use of Individual Air Pollution Monitors

for Direct Determination of Exposure.

2. Use of Individual Air Pollution Monitors to Adjust Results From Fixed Stations

3. Use of Representative Sampling to Determine Subgroup Exposure

4. Use of Individual Air Pollution Monitors to Calibrate Personal Activity Models.

Individual Monitors in Air Pollution Regulation...

Current Status and Research Needs

Conclusions.

RETERENGes

Appendix 


\section{INDIVIDUAL AIR POLLUTION MONITORS. 2. EXAMINATION OF SOME NONOCCUPATIONAL RESEARCH AND REGULATORY USES AND NEEDS}

\section{INTRODUCTION}

Despite decades of studying the health effects of chronic exposure to common air pollutants, there is little concensus among epidemiologists on the shape of health damage functions. Indeed, it is not clear if single-valued damage functions can be used to describe the damage processes. The experimental difficulties of such a study are considerable. Air pollution varies with place and time, people move around, the population receives not a single level of exposure but a range of exposures with different concentration-time histories. In addition, individual susceptibility to damage varies depending on age, health, previous exposure history, and genetic factors.

The weakest link in attempts to determine health damage functions is the accuracy of quantitative estimation of population exposure. ${ }^{1}$ Traditionally, studies of air pollution health effects have relied on one or several fixed monitoring stations to provide data for an estimate of the exposure received by a neighborhood or, not infrequently, by an entire city. ${ }^{2}$ Studies of this type have demonstrated a correlation between air pollutants and health effects. They have not been able to identify specifically the members of the population who are affected or the actual form of the damage functions. Despite the incomplete nature of this evidence, it was considered sufficient to serve as the basis for a public policy decision to institute air pollution controls. The Environmental Protection Agency's CHESS studies continued to follow the fixedmonitor approach, although care was taken to locate the stations in the immediate neighborhoods of the study populations. ${ }^{3}$

Epidemiologists have begun to call for something better. Several recent meetings of specialists in the field of air pollution health effects have led to recommendations urging the prompt development of small, portable individual air pollution monitors. ${ }^{4}$ A major study of simple individual monitor instruments has been initiated by a group at the Harvard School of Public Health with support from the National Institute of Environmental Health Sciences. ${ }^{5}$
In July 1975 the Biomedical and Environmental Assessment Group at Brookhaven National Laboratory convened a workshop of health effects and instrumentation specialists to consider the role of individual monitors in air pollution health effects studies and to assess research needs in this field. ${ }^{6}$ Two early conclusions of the workshop group were that "the importance of population exposure estimates in air pollution epidemiology makes it imperative that future epidemiological studies include exposure estimates more representative of what people actually breathe," and that "the use of individual air pollution monitors is a necessary factor in the design or performance of definitive studies of the health effects of air pollution."6

In the field of community air pollution, emphasis has been on general measures of air quality obtained from fixed sampling stations. In part, this is because the effects of interest have extended well beyond those of human health. Damage to materials and crops, soiling, decreased visibility, and ecological impacts are all important. Despite these considerations, health impacts are held paramount in the Clean Air Act. ${ }^{7}$ The primary standards established by EPA under that act are established solely on the basis of public health considerations. In light of this emphasis, it is surprising that greater attention is not given to actual population exposure levels by regulatory agencies.

In contrast, occupational exposure to air pollutants is regulated in terms of individual doses received by workers. Because of this different legal and regulatory environment, there has been considerable emphasis on developing individual monitors for use in the occupational field. Both the National Institute of Occupational Safety and Health and the Bureau of Mines have successful programs of research support in instrument development. ${ }^{8}$ A large number of commercial firms market individual monitoring instruments for occupational applications.

In this report we will review some of the evidence on the utility of fixed-station air pollution data for the estimation of individual dose. We will then examine the ways in which individual moni- 
tors might improve the determination of dose in health effects studies. We will also look briefly at possible regulatory applications of individual monitors. We will conclude by examining the current status of individual air pollution monitor instrumentation for use in ambient air and by summarizing the research needs in this field.

\section{AMBIENT LEVELS AND INDIVIDUAL EXPOSURE}

There is very limited knowledge of the relationship between ambient air pollution levels and individual dose. Indeed, there is rapidly growing evidence that measurements of ambient air quality at fixed monitoring stations may not give sufficient information on population exposure. (Exposure is used here to indicate what a person actually breathes. Exposure can be monitored by an instrument carried by the individual with an intake near the breathing zone. Dose refers to exposure to the tissue of interest, e.g., the lung.) To demonstrate the inadequacy of fixed-station data, we exa mine available evidence for exposure to carbon monoxide $(\mathrm{CO})$ and sulfur dioxide $\left(\mathrm{SO}_{2}\right)$.

Unlike most air pollutants, the carbon monoxide dose can be measured directly as carboxyhemoglobin $(\mathrm{C} \cap \mathrm{Hh})$. The relationship between the $\mathrm{CO}$ concentration in breathed air and the resulting carboxyhemoglobin level in blood is well understond "llurs, measurcments of COIIb concentration through blood tests, or alveular air tests, provide a direct measure of the intcyrated dose. Because $\mathrm{CO}$ is chemically stable, direct measurements of exposure can also be made by collecting calibrated air samples in the breathing zone for later analysis in the laboratory. These facts have seen remarkably limited application in air pollution health effects studies. However, results from several studies are available.

Ott and Mage $^{10}$ collected a total of 425 integrated CO samples over a period of 21 days in November $19^{\prime} / 0$ through January $19 \% 1$ in downtown San Jose, California. The samples were collected at breathing zone level while walking typical pedestrian routes. The resulting measurements were compared with those recorded by a nearby fixed monitor. Ott and Mage report that their individual simulated exposure sampling values "ranged as high as ten times the monitoring station values." The ratio of the average of all the ex- posure sampling data to the average of the fixedstation data was 1.6. Ott and Mage conclude that data from fixed stations ". . . provide a relatively poor measure of the true exposure of members of the general public to air pollutants ..."

Using grab samples, and, later, a portable $\mathrm{CO}$ instrument, Wright and Godin and their coworkers ${ }^{11,12}$ made extensive measurements of $\mathrm{CO}$ levels in Toronto. They demonstrated a "substantial discrepancy between the carbon monoxide concentrations detected by the Provincial network of fixed-site sampling stations and the much higher concentrations commonly met by people living and working in a large metropolitan area such as Toronto."12

Cortese and Spangler ${ }^{13}$ reported that mean $1-\mathrm{h}$ persunal exposurc of Boston commuters exceeded fixed-station measurements by a factor of 1.3 to 2.1; however, no significant increases in $\mathrm{COHb}$ levels due to commuting were observed.

Stewart and his co-workers have gathered extensive data on the $\mathrm{COHb}$ levels of American blood doners, ${ }^{14,15}$ and they have reported $\mathrm{COHb}$ levels higher than those that fixed-station data would lead one to expect.

Goldmuntz ${ }^{16}$ has correlated $\mathrm{COHb}$ data for nonsmokers collected from 1969 to 1972 by Stewart et al. ${ }^{15}$ with $\mathrm{CO}$ data collected by $37 \mathrm{EPA}$ fixed monitoring stations during 1973.17 The results are shown in Figure 1. The dashed curves show the least squares linear fits obtained by Goldmuntz, first for the entire set of points, and then for all but the four stations with the highest $\mathrm{CO}$ readings. Goldmuntz argues that it may be appro. priate to exclude these stations with high readings because of locational considerations.

We calculated the COHb levels one would expect if the population came to cquilibrium in an atmosphere with the $\mathrm{CO}$ level that was measured by the fixed station using the relation

$$
\% \mathrm{COHb}=[0.16 \times(\mathrm{CO}) \text { in } \mathrm{ppm}]+0.3 .
$$

This is bused wh a relationship derived by the California State Department of Public Health and reported by Goldsmith and Landaw ${ }^{18}$ with a ljackground $\mathrm{COHb}$ level of $0.3 \%$. In the region of interest $\left(1 \mathrm{mg} / \mathrm{m}^{3}\right.$ to $\left.10 \mathrm{mg} / \mathrm{m}^{3}\right)$, it is essentially the same as the relation derived by Stcwart, ${ }^{19}$ plotted as a solid curve in Figure 1. These data are listed in the Appendix. As in the studies previously cited, the measured $\mathrm{CO}$ concentration tends, for most 


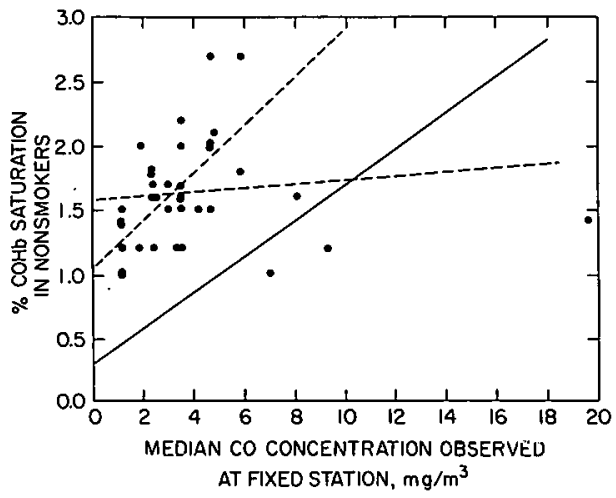

Figure 1. Correlation developed by Goldmuntz ${ }^{16}$ between 1969-1972 carboxyhemoglobin levels from nonsmoking blood donors and 1973 EPA fixed-station CO data. The dashed curves show the least squares linear fits obtained by Goldmuntz for the entire data set (low slope, correlation coefficient $r=0.06$ ) and for all but the four highest reading stations, which were excluded on locational grounds (high slope, correlation coefficient $r=0.64$ ). The solid curve shows the expected COHb levels if the population came to equilibrium in an atmosphere containing the $\mathrm{CO}$ levels measured by the fixed stations. ${ }^{18}$

of the fixed stations, to understate the expected $\mathrm{COHb}$ levels. The average dose indicated by $\mathrm{COHb}$ levels exceeded that predicted from fixedstation data by a factor of 2 .

Stewart et al. ${ }^{20}$ reported a similar analysis for Chicago, comparing 1970 and 1974 values. They observed COHb levels close to, but consistently higher than, those predicted from fixed-station data. They noted three problems associated with the use of fixed monitoring stations to define population exposure: The data may not reflect the worst exposure situations; the fixed stations are blind to indoor exposures to $\mathrm{CO}$ from cigarette smoke; and the fixed stations cannut detect exposures such as those resulting from faulty heating equipment.

Kahn et al. ${ }^{21}$ have demonstrated that $\mathrm{COHb}$ levels among nonsmokers in the St. Louis population are strongly affected by occupational exposure and by exposure to smokers. Both effects can be expected to influence the results in Figure 1, but the work of Ott and Mage and of Wright, Godin, and $\mathrm{n} n$-workers, reportcd above, sugyests that at lcast a portion of the difference observed between the levels measured at fixed stations and the levels encountered along the paths people move is not the result of occupational exposure or exposure to smokers.

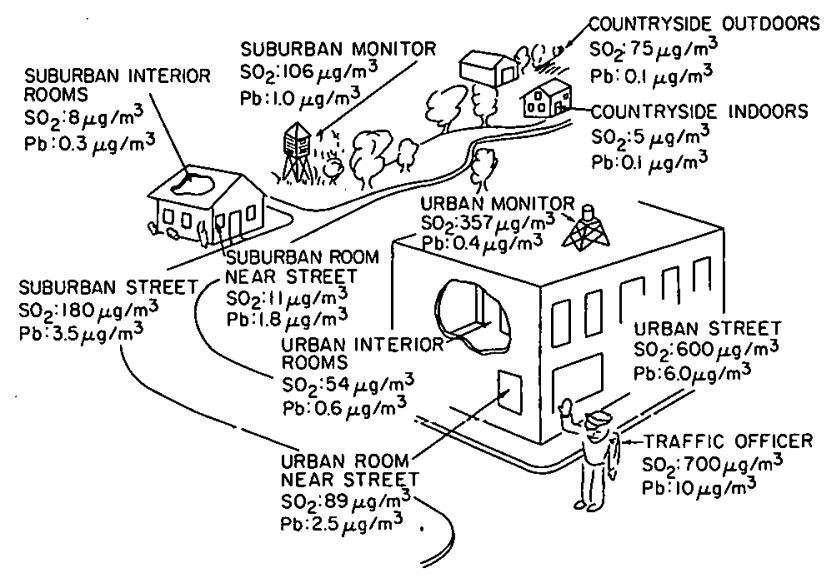

Figure 2. Average annual concentrations of sulfur dioxide and lead as measured by Fuga $^{22}$ in a medium-sized Yugoslav industrial city during the winter of 1972-73.

In the case of sulfur dioxide, a graphic illustration of the divergence between air quality as recorded at fixed stations and the $\mathrm{SO}_{2}$ levels to which people are actually exposed is provided by Fugaš in a study conducted in a middle-sized industrial city in Yugoslavia. ${ }^{22}$ Average concentration data obtained during the winter of 1972-73 are shown in Figure 2. Fugaš computes a weighted urban $\mathrm{SO}_{2}$ exposure of $101 \mu \mathrm{g} / \mathrm{m}^{3}(110 \mathrm{~h} /$ week in an urban home at $89 \mu \mathrm{g} / \mathrm{m}^{3} ; 42 \mathrm{~h} /$ week at work in the suburbs at $8 \mu \mathrm{g} / \mathrm{m}^{3} ; 10 \mathrm{~h} /$ week on an urban street at $600 \mu \mathrm{g} / \mathrm{m}^{3} ; 4 \mathrm{~h} /$ week on a suburban street at $180 \mu \mathrm{g} / \mathrm{m}^{3}$; and $2 \mathrm{~h} /$ week in the country at $25 \mu \mathrm{g} / \mathrm{m}^{3}$ ). The urban monitor level was 357 $\mu \mathrm{g} / \mathrm{m}^{3}$.

As an illustrative exercise, we have combined the $\mathrm{SO}_{2}$ concentration data reported by Fugaš with population data obtained from two middlesized U.S. cities. Note that while $\mathrm{SO}_{2}$ levels indicated in Figure 2 are significantly higher than current U.S. levels, it is the ratio between monitor readings and population exposure that is of primary importance.

From census data we can divide the population of the two U.S. cities into seven subgroups: 1) those who live and work indoors in the city; 2) those who live and work outdoors in the city (arbitrarily taken as $5 \%$ of all city workers); 3 ) those who live in the city and work indoors in the suburbs; 4) those who live and work indoors in the suburbs; 5) those who live and work outdoors in the suburbs (again taken as $5 \%$ of workers in this class); 6) those who live in the suburbs and work 
Table 1

First-Order Mobility Estimates Constructed for Two Sample Cities in the Northeast United States

(Numbers given are hours spent in each location. The column on the far right shows the average $\mathrm{SO}_{2}$ exposure that each population subgroup would receive if the air pollution levels shown in Figure 2 were applied.)

\begin{tabular}{|c|c|c|c|c|c|c|c|}
\hline Residence & Work place & $\begin{array}{c}\text { City } \\
\text { indoor } \\
\text { high } \\
\left(89 \mu \mathrm{g} / \mathrm{m}^{3}\right)\end{array}$ & $\begin{array}{c}\text { City } \\
\text { indoor } \\
\text { low } \\
\left(54 \mu \mathrm{g} / \mathrm{m}^{3}\right)\end{array}$ & $\begin{array}{c}\text { City } \\
\text { street } \\
\left(600 \mu \mathrm{g} / \mathrm{m}^{3}\right)\end{array}$ & $\begin{array}{c}\text { City } \\
\text { outdoor } \\
\text { work } \\
\left(400 \mu \mathrm{g} / \mathrm{m}^{3}\right)\end{array}$ & $\begin{array}{c}\text { City } \\
\text { suburban } \\
\text { commute } \\
\left(400 \mu \mathrm{g} / \mathrm{m}^{3}\right)\end{array}$ & $\begin{array}{c}\text { Surburban } \\
\text { indoor } \\
\text { high } \\
\left(11 \mu \mathrm{g} / \mathrm{m}^{3}\right)\end{array}$ \\
\hline 1. City & City, indoors & 6 & 17 & 1 & - & - & - \\
\hline 2. City & City, outdoors & 6 & 9 & 1 & 8 & - & - \\
\hline 3. City & Suburbs, indoors & 3 & 12 & - & - & 1 & 4 \\
\hline 4. Suburbs & Suburbs, indoors & - & - & - & - & 1 & 6.2 \\
\hline 5. Suburbs & Suburbs, outdoors & - & - & - & - & - & 6.2 \\
\hline 6. Suburbs & City, indoors & 6 & 2 & - & - & 1 & 5.7 \\
\hline 7. Suburbs & City, outdoors & - & - & - & 8 & 1 & 5.7 \\
\hline Residence & Work place & $\begin{array}{l}\text { Suburban } \\
\text { indoor } \\
\text { low } \\
\left(8 \mu \mathrm{g} / \mathrm{m}^{3}\right)\end{array}$ & $\begin{array}{c}\text { Suburban } \\
\text { street } \\
\left(100 \mu \mathrm{g} / \mathrm{m}^{3}\right)\end{array}$ & $\begin{array}{c}\text { Suburban } \\
\text { outdoor } \\
\text { work } \\
\left(143 \mu \mathrm{g} / \mathrm{m}^{3}\right)\end{array}$ & $\begin{array}{l}\text { Suburban } \\
\text { outdoor } \\
\text { recreation } \\
\left(106 \mu \mathrm{g} / \mathrm{m}^{3}\right)\end{array}$ & $\begin{array}{c}\text { Percent } \\
\text { of total } \\
\text { population }\end{array}$ & $\begin{array}{c}\text { Ann. av. } \\
\text { exposure } \\
\left(\mu \mathrm{g} / \mathrm{m}^{3}\right) \text { rec'd } \\
\text { by group }\end{array}$ \\
\hline 1. City & City, indoors & - & - & - & - & 30.6 & 86 \\
\hline 2. City & City, outdoors & - & - & - & - & 0.5 & 200 \\
\hline 3. City & Suburbs, indoors & 4 & - & - & - & . 1.6 & 58 \\
\hline 4. Suburbs & Suburbs, indoors & 17 & 0.5 & - & 0.3 & 59.2 & 14 \\
\hline 5. Suburbs & Suburbs, outdoors & 9 & 0.5 & 8 & 0.3 & 0.8 & 58 \\
\hline 6. Suburbs & City, indoors & 9 & - & - & 0.3 & 6.7 & 50 \\
\hline 7. Suburbs & City, outdoors & 9 & - & - & 0.3 & 0.4 & 157 \\
\hline
\end{tabular}

indoors in the city; and 7) those who live in the suburbs and work outdoors in the city (again 5\%). The ratios between these groups are almost prerisely the same for the two cities studied. We have made first-order mobility estimates for each gruup as shown in Table 1. On the basis of these estimates we have computed a histogram of average. annual exposure, Figure $3 a$, which upon differentiation yields the average annual population exposure distribution shown in Figure $3 b$.

Whether or not one arrepts the actual numbers involved in this example, it does seem safe to conclude that $\mathrm{SO}_{2}$ exposure estimates based on fixed monitnrs may display a marked bias. Health effect functions derived from such data may seriuusly misstate the health damage of a unit exposure.

In direct measurements made with individual air pollution monitors on a group of 20 school children in Ansonia, Connecticut, Binder et al. ${ }^{23}$ have obtained similar results. For $\mathrm{SO}_{2}$, they report mean 24-h personal exposure levels of $5.5 \pm 0.7$ $\mu \mathrm{g} / \mathrm{m}^{3}$ and mean outdoor monitor levels of $12.0 \pm$ $2.2 \mu \mathrm{g} / \mathrm{m}^{3}$. It is also of interest to note their cor- responding results for exposure to particulatcs and nitrogen dioxide $\left(\mathrm{NO}_{2}\right)$. For particulates, they report promonal exposure levels of $114.5 \pm 9.0 \mu \mathrm{g} / \mathrm{m}^{3}$ compared with $58.4+5.9 \mu \mathrm{g} / \mathrm{m}^{3}$ measured by fixed outdonr mnnitors; for $\mathrm{NO}_{2}$ their results are $61.3 \pm 7.2 \mu \mathrm{g} / \mathrm{m}^{3}$ compared with $100.1 \pm 9.0 \mu \mathrm{g} / \mathrm{m}^{3}$ outdoor levels. Exposure to particulates was significantly higher for those children with a smoker in the home. Exposure to $\mathrm{NO}_{2}$ was also higher, but neither the $\mathrm{NO}_{2}$ nor the $\mathrm{SO}_{2}$ exposure was significantly affected statistically by the presence of a smoker in the home.

A number of studies have explored aspects of the relationships between indoor (c.g., office, autn, home, tu.) and mitroor air pollution levels. ${ }^{24,25}$ Benson, Henderson, and Caldwell at EPA ${ }^{25}$ have advanced what they believe is an approximate relationship between indoor and outdoor levels of $\mathrm{SO}_{2}$. We attempted to use this relationship, together with population and air pollution data from our two sample U.S. cities, to recompute Figure $3 b$ with air pollution values more characteristic of those found in the United States today. However, 

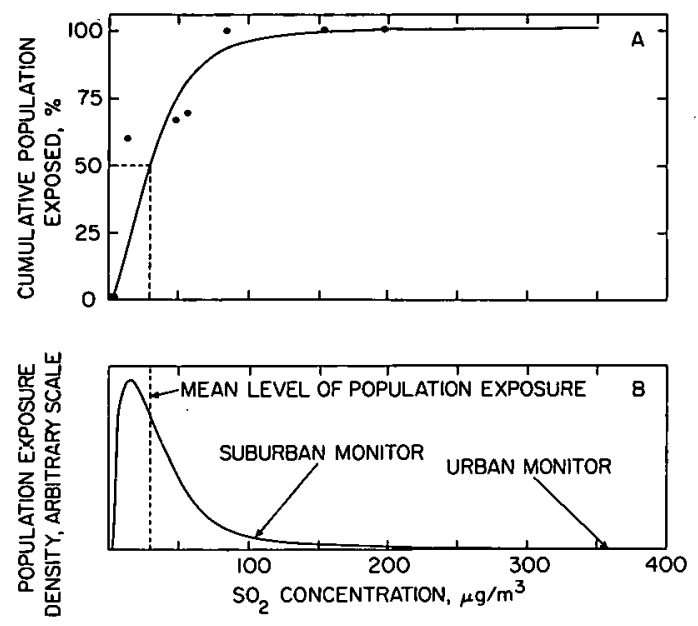

Figure 3. $A$ : Solid points mark the vertices of the histogram of annual exposure to $\mathrm{SO}_{2}$ obtained by combining the activity patterns of Table 1 with the air pollution levels of Figure 2. The histogram has been smoothed and is plotted as the solid curve. $B$ : Average annual population exposure obtained by differentiating the smoothed histogram in Figure $3 A$.

on close examination, the general relationship proposed by Benson et al. appears unreliable. The data on which this relationship was based are shown as solid points in Figure 4. The solid curve shows the proposed relationship. The dashed curve shows a linear least squares fit. In addition, we have computed urban, suburban, and rural indoorto-outdoor monitor ratios for the Fugaš data. These ratios have been plotted in Figure 4 as open circles.

It should be noted that most of the points lying on the solid curve in Figure 4 are from a single series of measurements performed in Cincinnati. Thus, there is reason to believe that a constant relationship may sometimes be found between indoor and outdoor $\mathrm{SO}_{2}$ levels for specific locations, as a function of time of year, building type, and so on, but appropriate studies have not been performed. Analysis of levels of other pollutants yields similar results. Studies by Yocum et al. ${ }^{26}$ in Hartford found indoor particulate levels that ranged from appruximately 20 to $50 \%$ of outdoor levels in the winter and from approximately 50 to $110 \%$ of outdoor levels in the summer, depending upon the type and location of the structure involved. The ratio does not appear to be a strong function of outdoor concentration.

Figure 3 suggests an important additional problem. As air pollution controls result in reduced

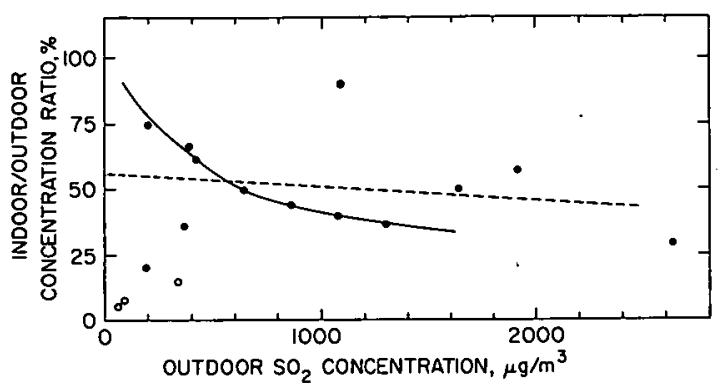

Figure 4. Benson et al. ${ }^{25}$ based their proposed relationship between indoor and outdoor air pollution levels (solid curve) on the data shown as solid points. Two of the data points they referenced appear to have involved indoor $\mathrm{SO}_{2}$ sources and have been excluded $\left(5.2 \mu \mathrm{g} / \mathrm{m}^{3}\right.$, $400 \%$; and $5.2 \mu \mathrm{g} / \mathrm{m}^{3}, 1600 \%$ ). The dashed curve shows a least squares linear fit to the solid points. The open points are derived from Fugaš. 22

fixed-monitor levels, it is not clear how individual doses will be reduced. At least in the case of $\mathrm{CO}$, where indoor sources are important, a reduction in fixed-monitor levels may not give rise to a proportional reduction in individual dose.

In summary, stationary air pollution monitors do not appear to provide reliable unbiased estimates of population exposure. There is some evidence that fixed-station data can understate actual population exposures to $\mathrm{CO}$ and overstate exposures to $\mathrm{SO}_{2}$. However, the relationship between fixed-station data and population exposures is not reliably known.

\section{INDIVIDUAL MONITORS IN HEALTH EFFECTS STUDIES}

A number of experimental designs have been proposed to improve individual exposure data used in health effects studies. The Brookhaven individual air pollution monitors workshop examined these designs and concluded that they all appear to require at least a limited usc of individual air pollution monitors. These designs can be grouped into four general categories.

\section{Use of Individual Air Pollution Monitors for Direct Determination of Exposure}

Each person in the study population would wear or carry an individual air pollution monitor during the course of the study. The same individuals would also be subject to continuous or periodic evaluation of health responses. Individual expo- 
sure and response would thus be measured on a one-to-one basis. Because of economic constraints, only relatively small populations could be studied by this direct approach.

\section{Use of Individual Air Pollution Monitors to Adjust Results From Fixed Stations}

As previously indicated, there can be substantial variations between area level measurements and personal exposure measurements. By monitoring exposure of individuals with individual air pollution monitors in areas also monitored with fixed stations, one would obtain the distribution of individual exposures in relation to measuremerıts obtained at the fixed stations. If one or several relatively constant relations were found in various areas, fixed-station data could then be corrected for use in estimating population exposures.

\section{Use of Representative Sampling to Determine Subgroup Exposure}

A carefully selected sample of the study population would be asked to wear or carry individual air pollution monitors. The sample would be stratified, grouping those expected to have similar exposures (e.g., office workers or street workers). The measured exposure of each subgroup in the sample could be used as representative for the entire group.

\section{Use of Individual Air Pollution Monitors to Calibrate Personal Activity Models}

Activity models have been developed that describe how and where people spend their time. ${ }^{27}$ Coupled with extensive fixed-station air pollution monitoring, including monitoring by instruments in representative homes, offices, etc., these models could prove to be useful in estimating population exposure. They have not been applied in air pollution epidemiology except in a very limited way, ${ }^{28}$ and they could be best calibrated or verified through experiments using individual air pollution monitors. In such an experiment, a carefully 38 lected sample of las: stuily population would he. asked to wear individual air pollution monitors, and their measured exposure would be compared with the estimated expusure of thc activity model.

\section{INDIVIDUAL MONITORS IN AIR POLLUTION REGULATION}

The most substantial impact that individual air pollution monitors could have on air pollution reg- ulatory policy would be through the revision of standards, or even the change of our basic regulatory philosophy, which could result from a more precise understanding of air pollution health damage functions. Of course, while the current primary standards are established on the basis of public health considerations, they also limit the environmental and esthetic impacts of air pollution, and it would be important to consider these impacts before undertaking any changes in current standards or regulatory philosophy.

There are a number of ways in which individual air pollution monitors might prove useful in the contcrt of regulatory activity that is designed to keep individual exposures below the presently established standards. To a limited extent, individual air pollution monitors may provc valuable in refining the choice of locations for fixed monitoring stations and in validating the air quality models that are based on these fixed-station data.

The current regulatory approach ignores individual indoor exposures such as those to smoky rooms ${ }^{29}$ or gas kitchen ranges. ${ }^{30}$ From a public health point of view, these exposures can contribute to excessive individual threshold exposures in the same way as exposures in outdoor air. Federal air pollution law dues not rcgulate such indoor exposures, but local public health authorities probably could intervene in some cases and several federal agencies, such as the Consumer Product Safety Commission, may also have jurisdiction over portions of the problem.

If air pollution represents a threat to public health, then it is clearly nul reasonable to limit our attention just to outdoor air, particularly since people spend the bulk of their time indoors. The key factor in determining public health impact is individual exposure history, and we believe that this history can be most directly obtained through the selective use of individual air pollution monitors.

\section{CIJRRENT STATUS AND RESEARCH NEEDS}

Althuugh there arć àctive fedes al iresrarch sup port programs and private industrial development programs for individual air pollution monitors for occupational use, few of the instruments developed under these programs are directly applicable to use in ambient air. Ditticulties encountered in dcveloping such instruments involve such factors as sensitivity, dynamic range, and running time. The Environmental Protection Agency has had a mod- 
Table 2

Tentative Ranking Developed by Participants in the Brookhaven Workshop on Individual Air Pollution Monitors of Candidate Gas- and Particle-Sensing Instrumentation Techniques

(Performance criteria applied in the ranking were the development of a prototype device of lunch box size or less with annual support of $\$ 200,000 /$ year or less. The rankings are not based on a full quantitative analysis and should be viewed only as a qualitative guideline.)

\begin{tabular}{|c|c|c|}
\hline Probability of Payoff & Within $<3 \mathrm{yr}$ & Within 3 to $6 \mathrm{yr}$ \\
\hline \multirow[t]{13}{*}{ Outstanding } & \multicolumn{2}{|l|}{ Gas Methods ${ }^{a}$} \\
\hline & Sorption & Sorption methods \\
\hline & Gel tape colorimetry & Colorimetry (tape based) \\
\hline & Electrochemical cells & Electrochemical cells \\
\hline & Coulometric and amperometric devices & Coulometric and amperometric devices \\
\hline & Fluorescence devices $\left(\mathrm{SO}_{2}\right)$ & Fluorescence devices $\left(\mathrm{SO}_{2}\right)$ \\
\hline & Nondispersive spectroscopy (CO) & Nondispersive spectroscopy (CO) \\
\hline & Chemiluminescence $\left(\mathrm{O}_{3}, \mathrm{NO}_{x}\right)$ & Chemiluminescence $\left(\mathrm{O}_{3}, \mathrm{NO}_{x}\right)$ \\
\hline & Particle Methods & \\
\hline & Virtual impactor $(M, 2 D, C)$ & Virtual impactor $(M, 2 D, C)$ \\
\hline & Filters $(M, \sim \mathcal{N}, \sim D, C)$ & Filters $(M, \sim \mathcal{N}, \sim D, C)$ \\
\hline & Diffusion batteries with filters $(C(D))$ & Diffusion batteries with filters $(C(D))$ \\
\hline & $\beta$ meter $(M)$ & $\begin{array}{l}\text { Optical scattering }(N, D) \\
\beta \text { meter }(M)\end{array}$ \\
\hline \multirow[t]{12}{*}{ Good } & \multicolumn{2}{|l|}{ Gas Methods } \\
\hline & Microwave devices (CO) & Electronic solid state devices \\
\hline & & \\
\hline & & Piezoelectric gas sensors \\
\hline & & Microwave devices (CO) \\
\hline & & Gas chromatography \\
\hline & \multicolumn{2}{|l|}{ Particle Methods } \\
\hline & Diffusion battery with & Virtual impactor $(M,>2 D, C)$ \\
\hline & rondensation nuclei counter $(\mathcal{N}, D)$ & $\begin{array}{l}\text { Diffusion battery with condensation } \\
\text { nuclei counter }(\mathcal{N}, D)\end{array}$ \\
\hline & & Piezoelectric mass balance \\
\hline & & $(M, \sim \mathcal{N}, \sim D)$ \\
\hline & & Optical scattering $(\sim \mathcal{N}, D)$ \\
\hline \multirow[t]{11}{*}{ Fair to poor } & \multicolumn{2}{|l|}{ Gas Methods } \\
\hline & Gas chromatography & Cryogenic sampling \\
\hline & Cryogenic sampling & Rinluminesoent metluuds \\
\hline & Elcctronil sulid státe devices & Optoacoustic methods \\
\hline & Nondispersive spectroscopy & Microwave devices \\
\hline & (gases other than $\mathrm{CO}$ ) & (gases other than $\mathrm{CO}$ ) \\
\hline & Piezoelectric gas sensors & \\
\hline & $\begin{array}{l}\text { Microwave devices } \\
\quad \text { (gases other than } \mathrm{CO} \text { ) }\end{array}$ & . \\
\hline & Particle Methons $^{\mathrm{c}}$ & \\
\hline & Piezoelectric mass balance $(M)$ & \\
\hline & Optical scattering $(\sim \mathcal{N}, D)$ & \\
\hline
\end{tabular}

a When the classification depends on the gas of interest, this has been indicated in parentheses. Techniques which were discussed but which the group did not feel qualified to evaluate included fluid-immersed solid state sensors and gas-sensitive liquid crystals.

${ }^{\mathrm{b}} M$ indicates device appropriate for measurement of total suspended particulate mass; $\mathcal{N}$, for measurement of total number of particles; and $D$, for measurement of particle size distribution. $2 D$ indicates that sizing into two categories such as $\geqslant 3 \mu \mathrm{m}$ and $\leqslant 3 \mu \mathrm{m}$ is possible. $C$ indicates device appropriate for collecting samples of particles for chemical analysis, and $C(D)$, that chemical composition can be estimated for two or more separate ranges of particle size.

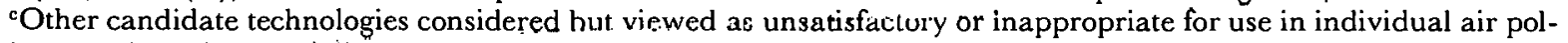
lution monitors included liquid impingers, centrifugal separation, conventional impactors, thermal precipitation, electrical mobility, and microwaves. 
est and sporadic development program for several years, ${ }^{31}$ and the Energy Research and Development Administration is beginning to support some work in this field but no comprehensive program of federal support currently exists for developing individual air pollution monitoring instruments for ambient air. The absence of a significant market for such instruments inhibits their development by private firms at this time.

The Brookhaven workshop produced a firstorder ranking of a number of the candidate instrumentation technologies according to promise of ultimate performance. These rankings, shown in Table 2, reflect a loose consensus of the participants at the time of the workshop and are useful as a qualitative guideline in evaluating the possibilities and research needs in the field of individual air pollution monitors. They should not be viewed as a firm evaluation. One of the first steps to be taken in developing a coherent program of long-term national support in this field is to make a more detailed evaluation of the relative potential of the various candidate technologies. ${ }^{32}$

For each technology, the workshop developed a first-order estimate of the research needs. It seems probable that a number of acceptable prototype devices could be produced within three years. The uncertainties about the ultimate performance of the various technologies are still sufficiently great, however, to preclude an immediate focusing on one or a ft:w approaches. It seems advisable to support development work on a number of the most promising technulugics in pus ullel for nt least three. years before concentrating on a smaller number for further development. The workshop report recommends a national R\&D investment of about eight million dollars over fivc years. This estımate is probably low. Some of the participants at the Rrnnkhaven workshop may have been overoptimistic in estimating the costs of developing prolutype instruments. Cost estimates were not included for field testing and production development. Industry participants made it clear that, with a few exceptions, the relatively modest market of a few thousand units or less, represented by individual air pollution monitors for use in epidemiological research, does not justify unsupported investments by industry for tooling and production costs. Huw= ever, if the same instruments can also be repackaged as small portable bench instruments, the market situation might be substantially improved.
Unit costs for active individual air pollution monitoring instruments can be expected to range from a few hundred dollars for tape-based colorimetric instruments to several thousands of dollars for gas fluorescence instruments. In the case of the more expensive instruments, it is unlikely that the nation can afford to outfit a number of separate experimental groups. Some arrangement for coordinated sharing between experimental groups will be required. Passive instruments with longer averaging times may be acceptable in some situations. One instrument operating on the principle of diffusion is now being produced for occupational monitoring at a cost of less than one dollar per unit. ${ }^{33}$

Development requirements and final unit costs are, to some degree, tied to the level of accuracy provided in the instrument. Accuracy better than 10 to $15 \%$ is probably not required. For some pollutants the expected range of exposures covers two orders of magnitude or more, and much valuablc information could be gained by using instruments accurate to a factor of 2 . The required accuracy and dynamic range depend critically on both the pollutant and the experimental context.

Studies using personal monitors, regardless of the instrumentation cost, will be expensive, will require the time and effort of valuable scientific manpower, and will produce data that will form a major base for air pollution - health decisions many years into the future. Before guidelines or specific:ations for the instruments to be developed are established, careful consideration must be given to expected devclupurent time, unit cost, institutional arrangements for sharing expensive instruments, and the implications of both instrument chararteristics and unit cost for experimental use.

\section{CONCLUSIONS}

Regulatory decisions on air pollution control, which involve direct and indirect costs of billions of dollars, are being made without adequate knowledge of the health impacts of air pollution. The weakest link in the studies of health effects is our knowledge of individual exposures. The importance of populalion exposure estimates makes it imperative that future studies include exposure estimates more representative of what people actually breathe. There are a number of experimental designs that can improve individual exposure data. 
Individual air pollution monitors easily carried or worn are necessary to the design or performance of all definitive studies of the health effects of air pollution. In addition to their importance to air pollution epidemiology, monitors may have potential regulatory applications.

Acceptable prototype devices could be produced within three years by a number of technologies. Because of the uncertainties regarding the ultimate performance of the several available technologies, it is recommended that support be given to the development of a number of the most promising technologies in parallel. A national R\&D effort of at least eight million dollars over a period of five years will be required.

Given the enormous costs involved in air pollution control and regulation and the considerable uncertainties in our present understanding of the health impacts of air pollution, a coordinated national program of support for the development of individual air pollution monitoring instruments should be initiated without delay.

\section{REFERENCES}

1. Jackson, D.L. and Newili, V.A., The strengths and weaknesses of population studies in assessing health effects, in Recent Advances in the Assessment of the Health Effects of Environmental Pollution (CEC/EPA/WHO 1974 Paris Conference Proceeding., Commission of the Eurupean Communities), EUR 5360, p. 161, Luxembourg, 1975.

2. For examples of such studies, see FERrIs, B.G. JR. AND Anderson, D.O., Proc. R. Soc. Med. 57, 979 (1964); Winkelstein, W., Kantor, S., Davis, E.W., Maneri, C.S., and Mosher, W.E., Arch. Environ. Health 14, 162 (1967); Buechley, R.W., Riggan, W.D., Hasselbad, V., and VanBruggen, J.B., Arch. Environ. Health 27, 134 (1973); Lave, L.B. and Seskin, E.P., J. Am. Stat. Assoc. 68, 284 (1973).

3. Health Consequences of Sulfur Oxides: A Report from CHESS, 1970-1971, Human Studies Laboratory, U.S. Environmental Protection Agency, EPA-650/1-74004, Research Triangle Park, NC, 1974.

4. See, for example, Conference Proceedings: Workshop on Health Effects of Fossil Fuel Combustion Products, Electric Power Research Institute, EPRI SR-11, Palo Alto, CA, 1975; Chemist/Metoorologist Wurksop 1975; Division of Biomedical and Environmental Research, U.S. Energy Research Development Administratinn, ERDA 1217-15, Washington, DC, 1976.

5. Speizer, F., Bishop, Y., and Ferris, B.G., An epidemiologic approach to the study of the health effects of air pollution, in Proceedings of the Fourth Symposium on Statistics and the Environment, American Statistical Association, 1977.
6. Morgan, M.G. and Morris, S.C., Individual Air Pollution Monitors. An Assessment of N National Research Needs, BNL 50482, Jan. 1976.

7. Clean Air Act, 42 U.S. Code 1857 et seq., see in particular Title 1, Section 109.

8. For a description of the research program supported by the Bureau of Mines, see Schnakenberg, George H., Coal Age 80, 84 (1975).

9. Goldsmith, J.R. and Landan, S.A., Science 162, 1352 (1968).

10. Ott, W.R. and Mage, David T., A method of simulating the true human exposure of critical population groups to air pollutants, in Recent Advances in the Assessment of the Health Effects of Environmental Pollution (CEC/ EPA/WHO 1974 Paris Conference Proceedings, Commission of the European Communities), p. 2097, EUR 5360, Luxembourg, 1975.

11. Godin, G., Wright, G., and Shepard, R.J., Arch. Environ. Health 25, 305 (1972).

12. Wright, G.R., Jewczyk, J., Onrot, J., Tomlinson, P., and Shepard, R.J., Arch. Environ. Health 30, 123 (1975).

13. Cortese, A.D. and Spengler, J.D., Ability of fixed monitoring stations to represent personal carbon monoxide exposure, J. Air Pollut. Control Assoc. 26, 1114 1150 (1976).

14. Stewart, R.D., Baretta, E.D., Platte, L.R., Stewart, E.B., Kalbfleisch, J.H., Van Yserloo, B., and RIMM, A.R., Science 182, 1362 (1973).

15. Stewart, R.D., Baretta, E.D., Platte, L.R., Stewart, E.B., Kalbfleisch, J.H., Van Yserloo, B., and Rimm, A.R., J. Am. Med. Assoc. 228, 1187 (1974).

16. Goldmuntz, L.A., Extent to Which Monitoring Station Measurements Reflect Human Exposure to Carbon Monoxide, Economics and Science Planning, Washington, DC, 1976.

17. Air Quality Data: 1973 Annual Statistics, U.S. Environmental Protection Agency, EPA-450/2-74-015, Research Triangle Park, NC, 1974.

18. Goldsmith, J.R. and Landaw, S.A., Carbon monoxide and human health, Science 162, 1352-1359 (1968).

19. STEwART, R.D., The effect of carbon monoxide on humans, Annu. Rev. Pharmacol. 15, 409-423 (19/5).

20. Stewart, R.D., Hake, C.L., Wu, A., Stewart, T.A., and Kalbfleisch, J.H., Carboxyhemoglobin trend in Chicago blood donors, 1970-1974, Arch. Environ. Health 31, 280-286 (1976).

21. Kahn, A., Rutledge, R.R., Davis, G.L., Altes, J.A., Ganiter, G.E., Thornton, C.A., and Wallace, N.D., Arch. Environ. Health 29, 127 (1974).

22. FuGA, M. in International Conforonoc on Encuinunmental Sensing and Assessment, Institute of Electrical and Electronics Engineers Catalogue, 75-CH 1004-1 ICESA, paper 38-5, Las Vegas, 1975.

23. Binder, R.E., Mitchell, C.A., Hosein, H.R., BouHuYs, A., Importance of the indoor environment in air pollution exposure, Arch. Environ. Health 31, 277 279 (1976).

24. Wade, W.A., Cote, W.A., and Yocom, J.E., J. Air Pollut. Control Assoc. 25, 933 (1975); Petersen, G.A. 
and Sabersky, R.H., Ibid. 25, 1028 (1975); Elliott, L.P. AND Rowe, D.R., Ibid. 25, 635 (1975).

25. Benson, F.B., Henderson, J.J., Caldwell, D.E., Indoor-Outdoor Air Pollution Relationships, VI A Literature Review, V2 An Annotated Bibliography, U.S. Environmental Protection Agency, AP-112 and AP-112b, Research Triangle Park, NC, 1972 and 1973.

26. Yocum, J.E., Cirink, W.L., Cote, W.A., J. Air Pollut. Control Assoc. 21, 251 (1971).

27. See, for example: Chapin, F.S., Human Activity Patterns in the City, Wiley-Interscience, New York, 1974.

28. Carnow, B.W., Lepper, M.H., Shekelle, R.B., and Stanler, J., Arch. Environ. Health 18, 768 (1969).

29. Bridge, D.P. and Corn, M., Environ. Res. 5, 347 (1968).

30. Cu'le, W.A., WAdE, W.A., Yorum. J.E., A Study of Indoor Air Quality, U.S. Environmental Protection
Agency, EPA-650/4-74-042, Research Triangle Park, NC, 1974.

31. Altshuller, A.P. and O'Keeffe, Andrew E., Personal and indoor exposure meters, in Recent Advances in the Assessment of the Health Effects of Environmental Pollution (CEC/EPA/WHO 1974 Paris Conference Proceedings, Commission of the European Communities), p. 2061, EUR 5360, Luxembourg, 1975.

32. A first step in this direction is represented by HARRISON, J.W., Gilbert, D.E., Lawless, P.A., and White, J.H., Development Strategy for Pollution Dosimetry, U.S. Environmental Protection Agency, EPA-600/2-76-034, Research Triangle Park, NC, 1976.

33. Palmes, E.D. and Gunnison, A.F., J. Am. Ind. Hyg. Assoc. 34, 78 (1973); Schnakenberg, G.H., A Passive Personal Sampler for Nitrogen Dioxide, U.S. Bureau of Mines, TPR 95, U.S: Department of the Interior, 1976. 
APPENDIX

Predicted and Observed Carboxyhemoglobin Levels in Nonsmokers at Various U.S. Locations

\begin{tabular}{|c|c|c|c|c|c|}
\hline $\mathrm{CO}$ monitoring station & $\begin{array}{l}\text { Blood donation } \\
\text { station }\end{array}$ & $\begin{array}{c}\text { Median } \\
\text { CO level } \\
\mathrm{mg} / \mathrm{m}^{3}\end{array}$ & $\begin{array}{c}\text { Observed } \\
\text { median } \\
\mathrm{COHb},{ }^{\mathrm{b}} \%\end{array}$ & $\begin{array}{l}\text { Predicted } \\
\text { COHb,c \% } \\
\text { (Base 0.3) }\end{array}$ & $\Delta$ \\
\hline Anchorage AK & Blood Center & & & & \\
\hline City Hall & 1020 I St. & 3.0 & 1.7 & 0.72 & 0.98 \\
\hline Phoenix, AZ & Blood Center & & & & \\
\hline 1845 E. Roosevelt St. & $1211 \mathrm{~W}$. Washington & 1.2 & 1.2 & 0.47 & 0.73 \\
\hline Anaheim, CA & Anaheim & 3.5 & 1.7 & 0.79 & 0.91 \\
\hline Azusa, CA & Duarte & 3.5 & 1.7 & 0.79 & 0.91 \\
\hline Burbank, CA & Burbank & 5.8 & 1.8 & 1.11 & 0.69 \\
\hline Costa Mesa, CA & Huntington Beach & 3.5 & 1.6 & 0.79 & 0.81 \\
\hline El Toro, CA & El Toro & 2.4 & 1.8 & 0.63 & 1.17 \\
\hline Lennex, CA & Hawthorne, CA & & & . & \\
\hline 11408 LaCienega & & 3.5 & 2.2 & 0.79 & 1.41 \\
\hline Long Beach, CA & Long Beach & 2.4 & 1.6 & 0.63 & 0.97 \\
\hline \multicolumn{6}{|l|}{ Los Angeles, CA } \\
\hline (1) 434 S. San Pedro & Downtown L.A. & 4.7 & 2.7 & 0.95 & 1.75 \\
\hline (2) 2351 Westwood & Westwood & 3.5 & 2.0 & 0.79 & 1.21 \\
\hline Pasadena, CA & Eagle Rock, CA & & & & \\
\hline 1196 E. Walnut & & 4.7 & 2.0 & 0.95 & 1.05 \\
\hline San Francisco, CA & Downtown & & & & \\
\hline 939 Ellis & & 2.4 & 1.8 & 0.63 & 1.17 \\
\hline Denver, CO & Blood Center & & & & \\
\hline E. Colfax and Colorado & 4200 E. 9th Ave. & 4.7 & 2.0 & 0.95 & 1.05 \\
\hline Washington, DC & VA Hospital & & & & \\
\hline 427 NJ Ave., N.W. & 50 Irving St. N.W. & 7.0 & 1.0 & 1.27 & -0.27 \\
\hline Miami, FL & Downtown & & & & \\
\hline I-95 \& Miami River & & 1.2 & 1.0 & 0.47 & 0.53 \\
\hline Honolulu, HI & Queens Hospital & & & & \\
\hline 1250 Punchbowl St. & 1301 Punchbowl St. & 3.5 & 1.2 & 0.79 & 0.41 \\
\hline \multicolumn{6}{|l|}{ Chicago, IL } \\
\hline (1) 445 S. Plymouth & Ward's Downtown & 5.8 & 2.7 & 1.11 & 1.59 \\
\hline (2) 538 S. Clark & M. Reese Hospital & 4.8 & 2.1 & 0.97 & 1.13 \\
\hline (3) Skokie, IL & A.B. Dick, Niles & 2.4 & 1.7 & 0.63 & 1.07 \\
\hline New Orleans, LA & Charity Hospital & 3.5 & 1.6 & 0.79 & 0.81 \\
\hline \multicolumn{6}{|l|}{ Detroit, MI } \\
\hline (1) 14590 Auburn & Bhai Brith, Southfield & 1.2 & 1.5 & 0.47 & 1.03 \\
\hline (2) 2451 Marquette & Ford Motor Corp. & 1.9 & 2.0 & 0.56 & 1.44 \\
\hline (3) Allen Park, MI & St. Pins, Southgate & 1.2 & 1.4 & 0.47 & 0.93 \\
\hline \multicolumn{6}{|l|}{ Et. Luuis, MO } \\
\hline (1) 8227 S. Broadway & LeMay & 1.8 & 1.2 & 0.55 & 0.65 \\
\hline (2) Clayton, MO & Brentwood & 2.5 & 1.6 & 0.65 & 0.95 \\
\hline (3) St. Ann, MO & Lambert Airport & 2.6 & 1.5 & 0.66 & 0.84 \\
\hline Elizabeth, N J & Elizabeth & & & & \\
\hline 7 Broad St. & & 4.2 & 1.5 & 0.88 & 0.62 \\
\hline \multicolumn{6}{|l|}{ New York, NY } \\
\hline (1) 59th St. \& Bridge Pl. & Manhattan & 19.6 & 1.4 & 3.02 & -1.62 \\
\hline (2) 3.50 Canal St. & Metropolitan Lifc & 9.3 & 1.2 & 1.59 & -0.39 \\
\hline Hempstead, NY & Long Island & 3.4 & 1.2 & 0.77 & 0.43 \\
\hline Salt Lake City, UT & Salt Lake City & 2.4 & 1.2 & 0.63 & 0.57 \\
\hline \multicolumn{6}{|l|}{ Seattle, WA } \\
\hline (1) 5th \& James & Blood Center & 4.7 & 1.5 & 0.95 & 0.55 \\
\hline (2) 6770 E. Marginal Way & Boeing Plant 2 & 3.5 & 1.5 & 0.79 & 0.71 \\
\hline (3) 4 th \& Pike & Downtown & 8.1 & 1.6 & 1.43 & 0.17 \\
\hline \multicolumn{6}{|l|}{ Milwaukee, WI } \\
\hline (1) 1225 S. Carferry & Allen Bradley Co. & 1.2 & 1.4 & 0.47 & 0.93 \\
\hline (2) 606 W. Kilbounh & Childrens Hospital & 1.2 & 1.0 & 0.47 & 0.53 \\
\hline
\end{tabular}

aMedian CO measurements at EPA monitoring stations compiled by L. Goldmunte. ${ }^{16}$

b Observed median $\mathrm{COHb}$ at blood donation stations as reported by Stewart et al. ${ }^{15}$

cPredicted $\mathrm{COHb}$ levels calculated from $\% \mathrm{COHb}=0.139(\mathrm{CO})$ in $\mathrm{mg} / \mathrm{m}^{3}+0.3$. 